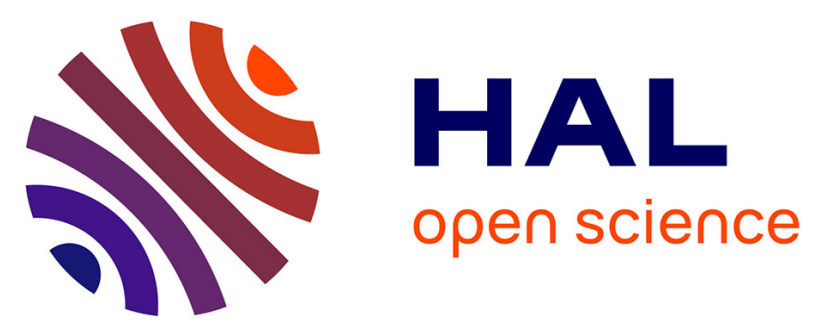

\title{
Canis spp. identification in central Mexico and its archaeological implications: toward a better understanding of the ecology and the cultural role of canids in ancient MesoAmerica
}

Aurélie Manin, Allowen Evin

\section{To cite this version:}

Aurélie Manin, Allowen Evin. Canis spp. identification in central Mexico and its archaeological implications: toward a better understanding of the ecology and the cultural role of canids in ancient MesoAmerica. Relations hommes - canidés de la Préhistoire aux périodes modernes, 2020. hal03051463

\section{HAL Id: hal-03051463 \\ https://hal.science/hal-03051463}

Submitted on 10 Dec 2020

HAL is a multi-disciplinary open access archive for the deposit and dissemination of scientific research documents, whether they are published or not. The documents may come from teaching and research institutions in France or abroad, or from public or private research centers.
L'archive ouverte pluridisciplinaire HAL, est destinée au dépôt et à la diffusion de documents scientifiques de niveau recherche, publiés ou non, émanant des établissements d'enseignement et de recherche français ou étrangers, des laboratoires publics ou privés. 


\title{
Canis Spp. identification in Central Mexico
}

\author{
AND ITS ARCHAEOLOGICALIMPLICATIONS :
}

\section{TOWARD A BETTER UNDERSTANDING OF THE ECOLOGY}

AND THE CULtURAL ROLE OF CANIDS IN ANCIENT MESOAMERICA

\section{INTRODUCTION}

Animal domestication induces not only biological changes of the targeted populations but also cultural shifts in the way the domesticated populations are perceived'. The grey wolf (Canis lupus) was certainly the first animal to be involved in this bio-cultural transformation, leading to the appearance of the dog (Canis familiaris) ${ }^{2}$, although the precise timing of this change is still intensely debated $^{3}$. Regardless, during the Late Upper Palaeolithic, alterations in the animal's morpholo$\mathrm{gy}^{4}$ and modifications in the behaviour of humans and "proto-domesticated dogs" alike $\mathrm{e}^{5}$ consensually characterise the early steps of dog domestication. Once domesticated, the dog accompanied human groups in their migrations across the world until regions where the wolf has never been present, such as Australia ${ }^{6}$ and South America ${ }^{7}$.
However, this strong relationship never became exclusive and human societies maintained strong economic and symbolic interactions with the dog's wild relatives. In Europe, the red fox (Vulpes vulpes) has been used, by turns, as a companion ${ }^{8}$ and a fur provider ${ }^{9}$. Archaeological evidence also points toward the symbolic consideration of the grey wolf in many cultures across the Northern hemisphere, as a participant in ritual paraphernalia ${ }^{10}$. Nonetheless, all the studies aiming at precisely reporting the distinct role of dogs and non-dog canids in the archaeological record have been hampered by the difficulty in identifying the different canid species from their osteological remains ${ }^{11}$.

With 18 to $20^{12}$ identified species ${ }^{13}$, the American continent hosts the largest diversity of canid species in the world. The multiplicity of biologically closely related species increases both the potential of interaction with human societies and the ambiguity in their skeletal identification. In Mesoamerica $^{14}$, four different species are present since the

8 Crandal-d'Anglade et al. 2019 (but see Janssens \& Lawler 2019 for a more nuanced interpretation); Cuthmann et al. 2016.

9 Baxter \& Hamilton-Dyer 2003; Bond 1996.

10 e.g. Losey et al. 2011; Pluskowski 2006; Sugiyama et al. 2014.

11 e.g. Lawrence 1967; Olsen 1985; Pluskowski 2006; Walker \& Frison 1982.

12 The status of two taxa, the Eastern wolf (Canis lycaon) and the red wolf (Canis rufus), is still debated as they arise from a fairly recent admixture between the wolf (Canis lupus) and the coyote (Canis latrans) while presenting increased fitness to their environment (vonHoldt et al 2016a; 2016b).

13 Wilson \& Reeder 2005.

14 Mesoamerica is a cultural area ranging from central Mexico to western Honduras arising among agricultural societies ca. 2500 a.C. Despite encompassing regions of contrasting environments, constant exchanges and trade allowed the 
beginning of the Holocene: the grey fox (Urocyon cinereoargenteus), the coyote (Canis latrans), the Mexican wolf (Canis lupus baileiy) and the dog ${ }^{15}$. Because of its very small size (on average $3-7 \mathrm{~kg}$ for a body length of $1 \mathrm{~m}$ including the tail' ${ }^{16}$ ), the grey fox can often be disentangled from the other species, even from fragmented bones. As a matter of fact, this species is often identified in the archaeozoological record, albeit never in large proportions ${ }^{17}$. It is particularly scarce in the iconography ${ }^{18}$ and, unlike the other canids, the fox does not stand as a particular symbol in the Mesoamerican cosmogony (see §Cultural background). Therefore, we focused our study on the identification of the three other species, namely the dog, the wolf and the coyote.

In this paper, we aim to deepen our understanding of the role of large canids (Canis spp.) in Mesoamerica by providing a more accurate identification of the canid remains to the species level. After introducing the ecological and cultural background of each animal, we first present a geometric morphometric (CMM) analysis of the first lower molar and test its efficiency to discriminate specimens of known species using a reference collection of 42 modern and archaeological specimens. This approach is then applied to 22 archaeological teeth, each from a unique individual, from four archaeological sites in central Mexico. The subsequent identification is used to contrast our perception of canid diversity and their interaction with human societies in the region.

emergence of a common tradition and its consolidation up to the beginning of the $16^{\text {th }}$ century p.C. (López Austin \& López Luján 2012; Matos Moctezuma 1994).

15 Arroyo Cabrales \& Carranza Castañeda 2009; Ceballos \& Arroyo Cabrales 2012.

16 Fritzell \& Haroldson 1982

17 e.g. Alvarez \& Ocaña 1999; Cötz 2008.

18 Seler 1996, 193.
Ecological background

It is now widely accepted that the dog has been introduced to America after its domestication from Eurasian wolves ${ }^{19}$ while no evidence for the local domestication of a population of American wolves has been identified so far. Cenetic evidence indicate that, outside of the Arctic region, the American dogs evolved in a distinctive monophyletic clade ${ }^{20}$. It is only after 1492, with the European colonisation and the introduction of large numbers of Eurasian dogs, that this lineage faded, until becoming virtually absent in modern populations, including in breeds of American origin ${ }^{21}$. In pre-Columbian Mesoamerica, carbon and nitrogen stable isotope analysis indicates that dogs often show similar diets to those of humans ${ }^{22}$. This trend has been interpreted as an evidence of their close relationship, whether dogs would have been fed purposely on household diet or were scavenging food waste and human faecal material ${ }^{23}$. In contrast, some individuals with more distant diets also suggest the presence of likely feral dogs, or at least loosely managed ones, around the settlements ${ }^{24}$

The Mexican wolf is the smallest subspecies of grey wolf ${ }^{25}$ and genomic analyses have shown a clear distinction from the other North American population ${ }^{26}$. Once inhabiting the dry pine-oak forests ranging from the Southern United States to the isthmus of Tehuantepec ${ }^{27}$, the subspecies was extinct in the wild by $1980^{28}$. Based on seven (captive) founder individuals, an intensive programme of captive breeding, management and release led to a new wild population of 21 Mexican wolves in

19 Leonard et al. 2002; Ní Leathlobhair et al. 2018.

20 Ameen et al 2019; Ní Leathlobhair et al. 2018.

21 van Asch et al. 2013; Castroviejo-Fisher et al. 2011; N hlobhair et al. 2018

22 Manin 2017a; White 2004

23 Cerry 1997; White et al. 2001; White \& Schwarcz 1989

24 White 2004; White et al. 2004

25 Bogan \& Mehlhop 1983; Hall \& Kelson 1959 vol.2, 847 .

26 Carcía Moreno et al. 1996; vonHoldt et al. 2011; Wayne et al. 1992.

27 Leopold 1959, 401

28 Brown 2002; cited by Harding et al. 2016.
Northern Mexico and around 100 in Arizona and New Mexico, according to a 2015-2016 census $^{29}$. Reports from the beginning of the 2oth century indicate that the Mexican wolves were hunted to extinction to protect livestock ${ }^{30}$. Nevertheless, studies of scats from wild Mexican wolves in the Blue Range Wolf Recovery Area (spanning between Arizona and New Mexico) show that their natural diet is centred on large preys, more specifically elk (Cervus elaphus) and deer (Odocoileus spp.) ${ }^{31}$.

The coyote is a widespread Nearctic canid Whereas Pleistocene deposits have yielded evidence of its presence as far south as Costa Rica ${ }^{32}$, climate change following the Late Pleistocene would have led to the contraction of its natural distribution to the north ${ }^{33}$. The coyote is particularly well adapted to prairies and human-modified environment, and during the last centuries, land clearance and the extirpation of its major predator, the wolf, have allowed the species to colonise most of North America and to extend across Central America ${ }^{34}$. In central Mexico, the coyotes feed mostly on small to medium preys (Lagomorpha, Rodentia), but also fruits during the wet season ${ }^{35}$, which would have all been available in the vicinity of ancient Mesoamerican settlements.

Due to habitat restriction and population depletion, hybridisation between coyotes and dog ${ }^{36}$ as well as wolves and coyotes $^{37}$ appear to be quite frequent amongst modern North American populations. Besides, pre-contact American dogs share some alleles with modern coyotes and North American wolves, indicating that this admixture goes back to prior $1492^{38}$. Whilst the spatiotemporal extent of this hybridisation is not well understood yet

29 Harding et al. 2016

(29 Hadingent 1959

31 Merkle et al. 2009; Reed et al. 2006

32 Lucas et al. 1997

33 Hody \& Kays 2018

34 Hidalgo-Mihart et al. 2004; Hody \& Kays 2018.

35 Aranda \& Lopez-de-Buen 1995: Hidalgo-Mihart et al. 2001

36 Adams et al. 2003; Schmutz et al. 2007

37 vonHoldt et al. 2011; 2016

38 Ní Leathlobhair et al. 2018. it may have played a role in the characterisation of wild and domestic populations alike.

\section{Cultural background}

Dogs and humans are closely associated in the Mesoamerican cosmogony. A Mexica belief, reported by the Spanish, tells us that only a dog was able to guide the spirit of the deceased through the death realm and to help him cross the Chiconahuapan river ${ }^{39}$. The presence of dog remains ${ }^{40}$ and dog effigies ${ }^{41}$ in human burials, or dog graves associated with funerary structures ${ }^{42}$ have all been interpreted as an evidence of those beliefs. In the Mexica mythology, Xolotl, the sky demon responsible for the movements of the stars, was represented by a $\operatorname{dog}^{43}$. But the presence of the dog in daily life is also illustrated by the rare architectural models characteristic of the Late Preclassic (300 a.C. - 300 p.C.) in Western Mexico. These complex ceramic objects represent domestic and village scenes where dogs are often depicted ${ }^{44}$. Testimonies of the early Spanish conquerors relate the consumption of dogs amongst the populations of central Mexico ${ }^{45}$, which is confirmed by recurrent presence of dog bones in Mesoamerican middens, sometimes presenting typical patterns of burning or cut marks ${ }^{46}$

The identification of other canid species is more heterogeneous. Whether looking at the iconography or the ethnohistoric records, there does not seem to be a straight discrimination between coyotes and wolves in Mesoamerica. In his Historia Ceneral de las Cosas de Nueva España, Fray Bernardino de Sahagun introduces the coiotl, an animal close to both the wolf and the fox but neither one of

39 de Sahagun 1829, 263

40 Martínez de León Mármol \& Reyes Carlo 2007.

41 Jarquin \& Martinez Vargas 2004

42 Rodríguez Calicia et al. 2001.

43 Seler 1996, 182

44 Day etal. 1996.

45 Diaz del Castillo 1996, 334; de Sahagun 1829, 160 46 e.g. Clutton-Brock \& Hammond 1994; Emery 2004; Manin \& Lefevre 2018, Valadez Azúa et al. 2013

47 de Sahagun 1830, 524 
He describes it as a fierce and resentful animal that does not hesitate to attack people and their domestic animals. Its Nahuatl name, coiotl, is at the origin of the modern term "coyote". A similar animal, only depicted in the Nahuatl version of this ethnohistoric work is the cuitlachtli that could correspond to the wolf ${ }^{48}$. Perhaps because of the transparency of the term coiotl, historians and archaeologists often identify the non-dog canids present in the Mesoamerican iconography and folklore as coyotes rather than wolves, even though no morphological or ethological reasons are given ${ }^{49}$

However, the coyote is particularly discrete in the archaeozoological record: our review of the literature found only six occurrences. Two individuals have been identified in the superficial layers of Cueva de las Varillas, in Teotihuacan, and interpreted as natural accumulation ${ }^{50}$. Still in Teotihuacan, one coyote has been identified in burial 6 of the Moon Pyramid ${ }^{51}$. In Western Mexico, on the site of Malpaís Prieto, a complete radius found in the midden of an elite house is particularly slender, and it was identified as a possible coyote ${ }^{52}$. Finally, two potential individuals (cf. Canis latrans) are mentioned in the Late Postclassic and Colonial occupation of Tipu, Guatemala ${ }^{53}$. Nonetheless, many authors maintained their identification to the level of the genus (Canis sp.), acknowledging the possible presence of coyotes $^{54}$.

Without being largely more common than the coyote yet, the wolf is more frequent in the archaeozoological record and always associated with extraordinary deposits. In Teotihuacan, in the dedicatory burials of the Moon Pyramid (burial 2, 4 and 6), the remains of at least 22 wolves were present ${ }^{55}$ and others were found in the Quetzalcoatl Pyra-

48 Blanco et al. 2007

49 e.g. Carballo 2007; Kubler 1972; Seler 1996, 193

50 Valadez Azúa \& Rodríguez Calicia 2009, 622.

51 Sugiyama et al. 2014

52 Manin 2015, 316

53 Emery 1999

54 e.g. Álvarez \& Ocaña 1999; Valentín Maldonado 1997.

55 Sugiyama \&López Luján 2006; Sugiyama et al. 2014. mid, although there is no count ${ }^{56}$. Several skeletons of wolves were of Mexico Tenochtitlan ${ }^{57}$, including two complete individuals (offerings 120 and 125) richly adorned with green-stone beads, shell pendants and gold and copper bells $s^{58}$. Other findings include various remains from tronco-conical pits in Cuanalan, $\mathrm{Ba}$ $\sin$ of $\mathrm{Mexico}^{59}$, and a single isolated mandible in a ceremonial cache in Cantona, Puebla ${ }^{60}$.

It appears from this brief overview that the dogs, the coyotes and the wolves present distinct behaviours and ecological characteristics ranging from domestic (dogs) to commensal (coyotes) and wild animals (wolves). This gradient might be reflected in their cultural perception in ancient Mesoamerica, denoting their relative proximity to the anthropized environment and hence human settlements. Therefore, a more systematic identification of the remains in the archaeozoological record would enhance our understanding of the relationships between human societies and canid populations.

\section{TOOTH GEOMETRIC MORPHOMETRICS TESTING A "NEW" TOO \\ FOR CANID SPECIES IDENTIFICATION}

Ceometric morphometrics (CMM) is an approach allowing the precise capture of phenotypic variations ${ }^{61}$. Because, in mammals, the shape of each tooth is strictly controlled by complex genetic signals ${ }^{62}$ and this tissue is hardly ever remodelled through the lifetime of an individual ${ }^{63}$, tooth morphometry is believed to retain a strong taxonomic and phylogenetic signal. Indeed, recent CMM

56 Álvarez \& Ocaña 1999, 82

57 Álvarez \& Ocaña 1999, 82

58 López Luján \& Chavez Balderas 2010; López Luján et al. 2012.

59 Álvarez \& Ocaña 1999, 82

60 Valentín Maldonado com. pers. 2014

61 Adams et al. 2004, 2013.

62 Jernvall \& Thesleff 2000; Thesleff 2006

63 Hillson 2005, 152. application to archaeological teeth of rodents ${ }^{64}$ pigs $^{65}$ or equids ${ }^{66}$ have shown the potential of this approach to refine taxonomic identification of ancient remains and unravel population history. Yet, while canid complete skulls and mandibles have been the object of in-depth CMM analyses ${ }^{67}$, single-tooth morphometrics have been studied less intensively ${ }^{68}$.

\section{Reference collection}

In order to distinguish between the three species of Mesoamerican large canids, we developed a two dimensional CMM protocol on the first lower molar. Forty-two teeth (one per individual) of known species were first analysed (tab. 1). They consist in 16 modern coyotes, 10 modern wolves, 8 modern dogs and 8 archaeological Mesoamerican dogs genetically identified in previous studies ${ }^{69}$. All specimens were adults with fully erupted first molars.

When selecting the wolves, priority was given to the Mexican subspecies, whether they were wild or captive $(\mathrm{N}=2)$. A very limited number of individuals was available within this category ${ }^{70}$, which can be related to the scarcity of the population in the wild. Thus the sampling was extended to wild individuals of known provenience $(\mathrm{N}=8)$. Individuals which skull presented "dog" characteristics such as a steep angle between the forehead and the snout ${ }^{71}$ and a larger orbital angle ${ }^{72}$, were considered as questionable identification and not used for this study. Simi-

64 Cucchi et al. 2013; Hulme-Beaman et al. 2018; ValenzuelaLamas et al. 2011

65 Cucchi et al. 2011; Evin et al. 2013; 2015.

66 Cucchi et al. 2017; Seetah et al. 2014.

67 Ameen et al. 2019; Drake et al. 2017; Drake \& Klingenberg 2010. Fisher 2019; de Moura Bubadué et al. 2016; Schmitt \& 2010; Fisher 2019; de Moura $\mathrm{B}$
Wallace 2014.

68 Amano 2011; Pionnier-Capitan 2010

69 Manin et al. 2018; Ní Leathlobhairet al. 2018.

70 Our study was carried out mainly in the collections of Anatomie Comparee of the Museum national dHistoire naturelle, with a short complementary stay in the Laboratorio de Arqueozoología M. en C. Ticul Alvarez del Instituto Naciona

7 Lawrence \& Bossert 1967.

72 Illin 1941 larly, Eastern and red wolves were not considered in this study as they may represent different degrees of hybridisation between wolves, coyotes, and dogs to a lesser extent ${ }^{73}$.

Because they would match the expected size and robustness of ancient Mesoamerican dogs ${ }^{74}$ seven modern dogs used as reference were chosen amongst dolicocephalic / mesocephalic and medium-sized breeds. One village dog from Northern Peru, affected with canine ectodermal dysplasia (CED), was also included. Although this congenital defect also impacts the teeth morphology ${ }^{75}$, all the landmarks used in our protocol were visible on this individual. Because our archaeological collection included dogs potentially affected by $\mathrm{CED}^{76}$, it appeared particularly useful to consider this variation in the tooth morphology. Finally, we used eight archaeological dog mandibles from Tizayuca, Basin of Mexico, that were previously identified as dogs based on their metrics and mitochondrial DNA ${ }^{77}$.

\section{Archaeological samples}

A total of 22 teeth of unidentified canids from four archaeological sites of central Mexico (fig. 1) was analysed for species identification. All the teeth were fully mineralised and showed limited wear. All the landmarks used in our protocol were visible on each of these teeth.

The site of Nogales represents the western end of the collection analysed in this study. It was occupied by sedentary agriculturalists from ca. 500 p.C. until its abandonment around 1000 p.C.; a brief re-occupation by groups of hunters is noted ca. 1450-1500 p.C. ${ }^{78}$. A fragmented mandible analysed in this study comes from the early occupation of the site, around 500 p.C., and was found in the filling

73 vonHoldt et al. 2011

74 Blanco Padilla et al. 2009

75 Kupczik et al. 2017; Shirokova et al. 2013

76 Manin et al. 2018

77 Manin et al. 2018; Ní Leathlobhair et al. 2018

78 Pereira 2008 


\begin{tabular}{|c|c|c|c|c|c|}
\hline Individual & Species & Category & Origin & $\begin{array}{l}\text { Logarithm of the } \\
\text { centroid size }\end{array}$ & Det \\
\hline MNHN-ZO-1928-1912 & Canis latrans & Modern & Mexico city, Mexico" & 1,725 & Coyote \\
\hline MNHN-ZO-1887-1253 & Canislatrans & Modern & Mexico & 1,544 & Coyote \\
\hline MNHN-ZO-2007-454 & Canis latrans & Modern & USA & 1,730 & Coyote \\
\hline MNHN-ZO-2007-456 & Canis latrans & Modern & Kansas, USA & 1,747 & Coyote \\
\hline MNHN-ZO-2007-457 & Canis latrans & Modern & Unknown & 1,819 & Coyote \\
\hline MNHN-ZO-2007-458 & Canis latrans & Modern & Michigan, USA & 1,862 & Coyote \\
\hline MNHN-ZO-1962-966 & Canis latrans & Modern & Texas, USA & 1,867 & Coyote \\
\hline MNHN-ZO-1962-967 & Canis latrans & Modern & Pensylvania, USA & 1,857 & Coyote \\
\hline MNHN-ZO-1880-839 & Canis latrans & Modern & Unknown & 1,689 & Coyote \\
\hline MNHN-ZO-1929-280 & Canislatrans & Modern & Unknown & 1,752 & Coyote \\
\hline MNHN-ZO-1931-691 & Canis latrans & Modern & Unknown & 1,795 & Coyote \\
\hline INAH-1539 & Canis latrans & Modern & Mexico & 1,780 & Coyote \\
\hline INAH-7270 & Canis latrans & Modern & Mexico & 1,775 & Coyote \\
\hline INAH-7753 & Canis latrans & Modern & Mexico & 1,804 & Coyote \\
\hline INAH-7754 & Canis latrans & Modern & Mexico & 1,652 & Coyote \\
\hline INAH-7755 & Canis latrans & Modern & Mexico & 1,744 & Coyote \\
\hline MNHN-ZO-1997-457 & Canis lupus & Modern & Pyrenees, France & 2,098 & Wolf \\
\hline INAH-7757 & Canis lupus bayleyi & Modern & Mexico & 1,918 & Wolf \\
\hline MNHN-ZO-1927-2353 & Canis lupus bayleyi & Modern & Mexico city, Mexico" & 1,977 & Wolf \\
\hline MNHN-ZO-1990-23 & Canis lupus & Modern & Quebec, Canada & 2,050 & Wolf \\
\hline MNHN-ZO-1911-754 & Canis lupus & Modern & Xinjiang, China & 2,068 & Wolf \\
\hline MNHN-ZO-1997-452 & Canis lupus & Modern & Lubelskie, Poland & 2,04 & Wolf \\
\hline MNHN-ZO-1974-339 & Canis lupus & Modern & Kurdistan, Iran & 1,958 & Wolf \\
\hline MNHN-ZO-1974-340 & Canis lupus & Modern & Hamadan, Iran & 2,002 & Wolf \\
\hline MNHN-ZO-1962-1525 & Canis lupus & Modern & Unknown (Rusian wolf) & 2,187 & Wolf \\
\hline MNHN-ZO-1934-72 & Canis lupus & Modern & Unknown (Arctic wolf) & 2,041 & Wolf \\
\hline MNHN-ZO-1985-1208 & Canis familiaris & Modern & France (Brittany spaniel) & 1,801 & Dog \\
\hline MNHN-ZO-1985-1216 & Canisfamiliaris & Modern & France (Belgian Shepherd Dog) & 1,811 & Dog \\
\hline MNHN-ZO-1985-1219 & Canis familiaris & Modern & France (Cocker) & 1,717 & Dog \\
\hline MNHN-ZO-1985-1232 & Canis familiaris & Modern & France (Brittany spaniel) & 1,819 & Dog \\
\hline MNHN-ZO-1985-1259 & Canis familiaris & Modern & France (Brittany spaniel) & 1,768 & Dog \\
\hline MNHN-ZO-1985-1289 & Canis familiaris & Modern & France (Dachshund) & 1,619 & Dog \\
\hline MNHN-ZO-1985-1297 & Canis familiaris & Modern & France (Cerman Shorthaired Pointer) & 1,810 & Dog \\
\hline Peru_mandor & Canis familiaris & Modern & Peru & 1,721 & Dog \\
\hline MT-01 & Canis familiaris & Archaeological & Tizayuca, Hidalgo, Mexico & 1,659 & Dog \\
\hline MT-02 & Canis familiaris & Archaeological & Tizayuca, Hidalgo, Mexico & 1,771 & Dog \\
\hline MT-04 & Canis familiaris & Archaeological & Tizayuca, Hidalgo, Mexico & 1,720 & Dog \\
\hline MT-05 & Canisfamiliaris & Archaeological & Tizayuca, Hidalgo, Mexico & 1,673 & Dog \\
\hline MT-08 & Canis familiaris & Archaeological & Tizayuca, Hidalgo, Mexico & 1,734 & Dog \\
\hline MT-15 & Canisfamiliaris & Archaeological & Tizayuca, Hidalgo, Mexico & 1,718 & Dog \\
\hline MT-17 & Canisfamiliaris & Archaeological & Tizayuca, Hidalgo, Mexico & 1,671 & Dog \\
\hline MT-20 & Canis familiaris & Archaeological & Tizayuca, Hidalgo, Mexico & 1,690 & Dog \\
\hline
\end{tabular}

Tab. 1. List of the samples in the reference collection.

*: Captive individuals from the Zoologico de Chapultepec.

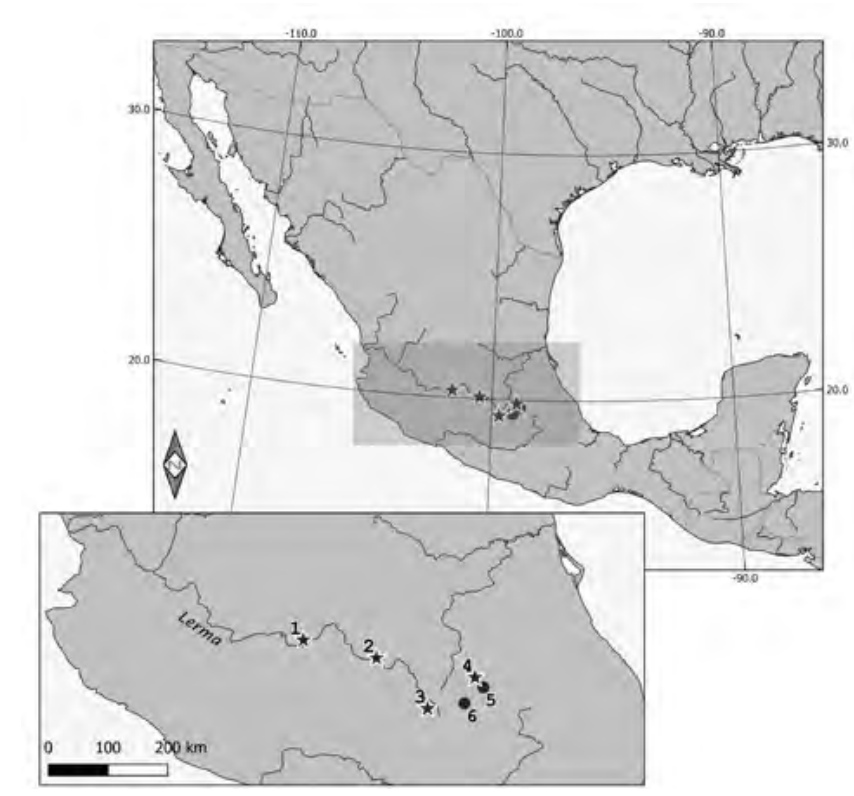

Fig. 1. Location of the sites analysed in this study (stars) and the main sites mentionedin the text (dots).

$=$ Nogales; $2=$ = TR74; $3=$ Calixtlahuace

$4=$ Tizayuca; 5 = Teotihuacan; 6 = México-Tenochtitlan.

of a platform. The other two remains were isolated teeth found in disturbed layers.

The site of El Mezquite - Los Azules (JR74) is located in the cradle of the Chupicuaro culture, in the Lerma basin ${ }^{79}$ and was occupied from ca. 600 a.C. to $400 \mathrm{p.C} .^{80}$. The sample analysed in this study comes from an isolated mandible found in the filling of a Chupicuaro structure dated to the Classic period between 250 p.C. and 400 p.C. ${ }^{81}$.

Calixtlahuaca is a large urban centre located in the Toluca valley and occupied between ca. 1100 and 1530 p.C. Historical documents indicate that the city was conquered by the Aztecs of the triple alliance between 1475 and 1478. In 1530, in order to establish their authority on the valley, the Spaniards evacuate the city and relocate its inhabitants in Toluca ${ }^{82}$. The zooarchaeological analysis shows that the canids were the taxonomic group the most represented in the site, both in terms of NISP (88;

79 Porter 1956.

80 Faugère in prep.

81 Manin in prep.

82 Huster \& Smith 2015; Tomaszewski \& Smith 2011
$55 \%$ of the total NISP) and MNI $(5 ; 24 \%$ of the total $\mathrm{MNI})^{83}$. The two samples analysed here come from structure 307 , the domestic midden of a high-status residence associated with the Ninupi phase (13801450 p.C.).

Tizayuca is a settlement located in the basin of Mexico. Architectural, lithic and ceramic remains from the Teotihuacan complex, Toltec and Aztec cultures, as well as sporadic Colonial elements indicate that the area was occupied persistently from 200 to 1520 p.C. However, the stratigraphic layers were particularly thin and prevented the clear chronological attribution of the bone remains ${ }^{84}$. As in Calixtlahuaca, the canids outnumbered the other taxa (NISP $=877$, or $25 \%$ of the total NISP; MNI $=42$ ). Three adults and one juvenile canids were found in burials, the adults being all identified as dogs on the basis of their mitochondrial DNA ${ }^{85}$. Sixteen first lower molars of unidentified canids were analysed in this study.

83 Manin 2017b; 2015, 160

84 Equihua et al. 2008.

85 Manin et al. 2018; Ní Leathlobhair et al. 2018. 
Method

Each tooth was photographed on the occlusal view using a standardised protocol. The teeth were positioned with the talonid being on a horizontal plan and photographed using a Canon EOS 1000D digital camera equipped with a 70-300 mm macro lens. Tooth shape was assessed by digitising five landmark and 60 sliding semi-landmark coordinates on the images (fig. 2) using tpsDig2 v2.1986. Superimposition and subsequent statistical analyses were performed using R $3 \cdot 5 \cdot 3^{87}$. The coordinates of the different specimens were superimposed and scaled using the Morpho package ${ }^{88}$. Size analyses were based on the log-transformed centroid size and shape analyses were based on the Procruste residuals (coordinates after superimposition). Differences in size were tested using Kruskal-Wallis and Wilcoxon tests and visualised by boxplots. Analysis of shape variation was based on a principal component analysis (PCA), before testing the differences between groups using multivariate analysis of variance (MANOVA) and linear discriminant analysis (LDA) after reduction of the dimensionality of the data ${ }^{89}$. The LDA was paired with a leave-one-out cross validation assessing the discriminant power of the analysis. The threshold to confidently identify an individual was set to $95 \%$. Identifications made with a probability of $75 \%$ to $95 \%$ were only considered as plausible.

Statistical tests were performed using a reference threshold of $\alpha=0.05$ on $R$ v3.5.3

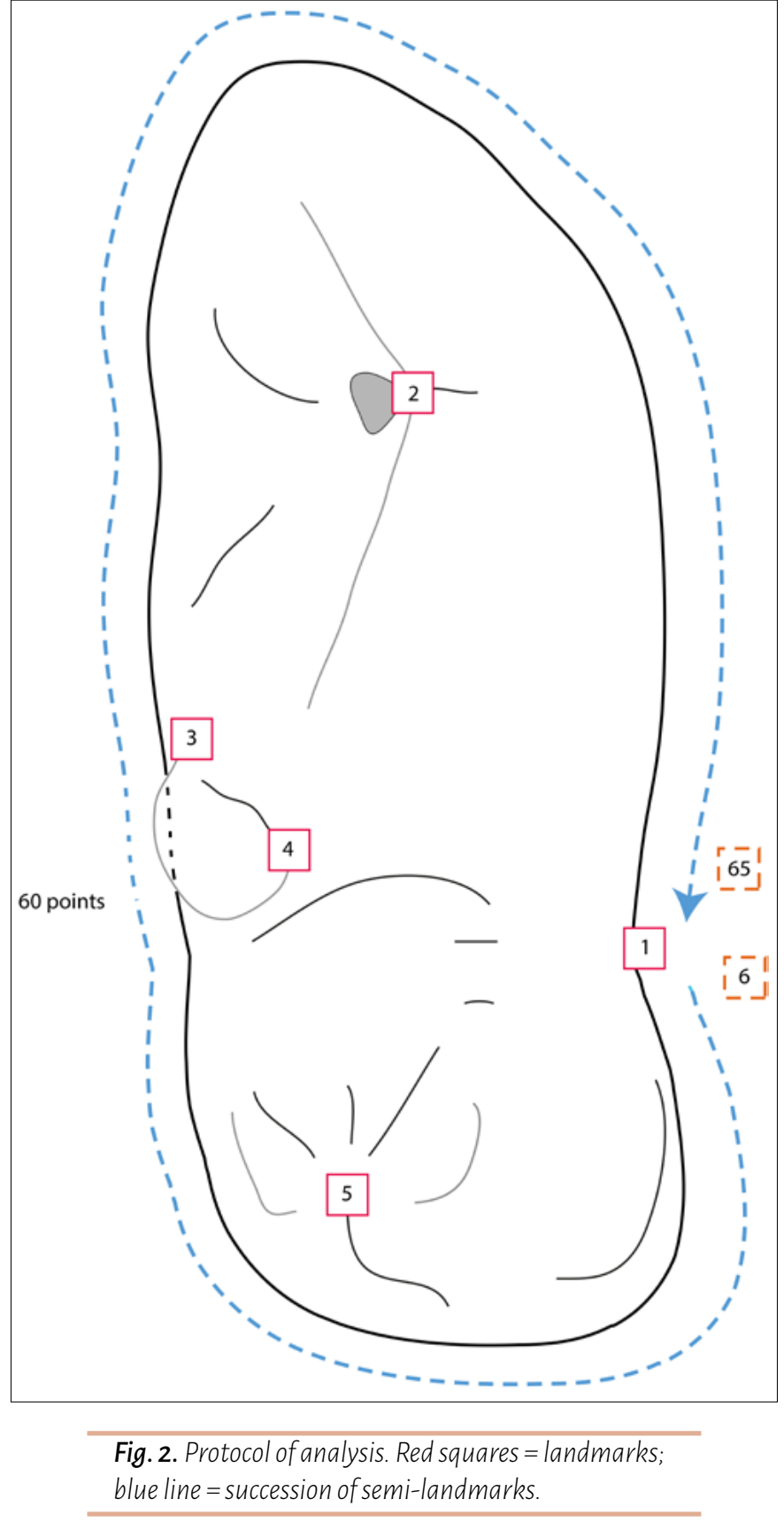

86 Rohlf 2015.

87 R Core Team 2019.

88 Schlager 2017.

89 Baylac \& Friess 2005

90 R Core Team 2019.

\section{IDENTIFYING THE CANID SPECIES PRESENT} in Central Mexico

Coyotes, dogs an wolves from the reference dataset differ in size (Kruskal-Wallis test, $\mathrm{H}=23.5$, $\mathrm{df}=2, \mathrm{p}=8 \mathrm{e}-6$ ), although when they are compared two by two only the wolf differs from the others (Wilcoxon test, $p=3.8 \mathrm{e}-7$ for both comparisons), while the coyote does not differ in size from the dog ( $p=0.17)$ (fig. 3). The molar log-transformed centroid size of the wolf ranges from 1.918 to 2.187 that of the coyote from 1.554 to 1.867 and that of the dog from 1.619 to 1.819 (fig. 3). The molar size of the unknown archaeological samples ranges from 1.637 to 1.799 (tab. 2) overlapping the sizes of the dogs $(p=0.052)$ while being slightly smaller than the coyote $(p=0.0016)$ and considerably smaller than what we observed in wolves ( $p=1.9 e-7$ ) (fig. 3).

The first two axes of the shape PCA $21.55 \%$ and $15.96 \%$ of total variance respectively, fig. 4), tend to separate wolves from the other groups. While coyotes and archaeological unidentified specimens are clearly separated from the wolves, the reference group of dogs (including both modern and archaeological) overlap with wolves and coyotes along axis one, and mostly with coyotes along axis 2 . The unidentified archaeological specimens clearly overlap with the coyotes and the dogs, and not a single one overlap with the wolves.

The three reference taxa differ in their first lower molar shape $(F(10,72)=16.369, p=6 \mathrm{e}-15)$, and the discriminant analysis reach $88.3 \%$ of correct cross validation. The dog and the coyote are differentiated along the first discriminant axis $(67.1 \%$ of the total variation, fig. 5) while the wolf differentiates along the second component $32.9 \%$ of the total variation). Predicted position of most of the archaeological unknown specimens overlaps with the dog except one (fig. 5). Among the unknown archaeological specimens, 18 dogs were identified with a probability ranging from $96.7 \%$ to $100 \%$ (tab. 2). Lower probabilities of identification led to the identification of two 'possible dogs' with probabilities of identification of $75.1 \%$ (MT18) and $80.1 \%$ (MT25) and one 'possible coyote' (MT14) identified with a probability of $86.2 \%$. Finally, the last specimen (MT24) was identified with a probability of $69.7 \%$ to dog, $22.7 \%$ to coyote and $7.6 \%$ to wolf and was left unidentified (tab. 2)

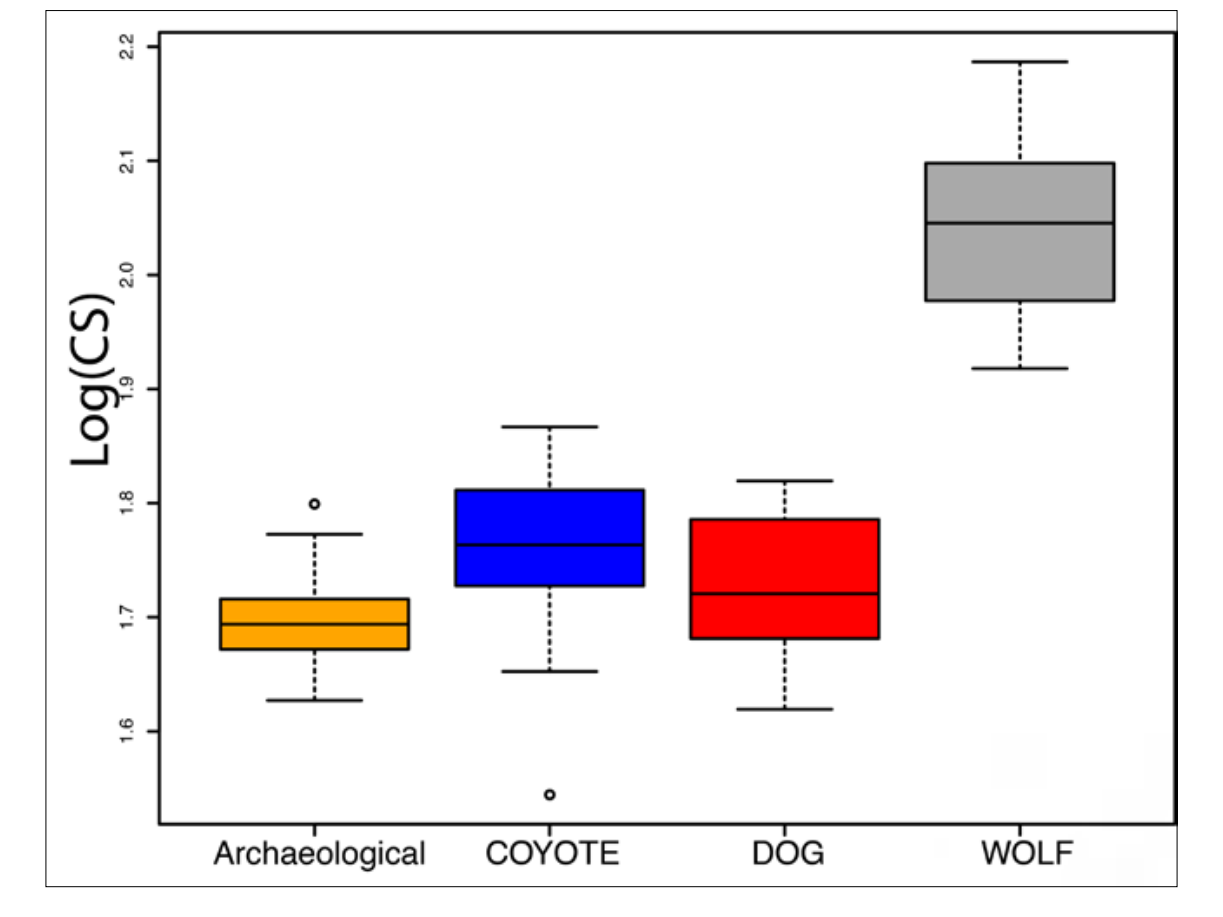

Fig. 3. Boxplot of the logarithm of the centroid size (LogCS) amongst the reference groups and the archaeological unidentified specimens. 


\begin{tabular}{|c|c|c|c|c|}
\hline \multirow[b]{2}{*}{ Individual } & \multirow[b]{2}{*}{$\begin{array}{l}\text { Logarithm of the } \\
\text { centroid size }\end{array}$} & \multicolumn{3}{|c|}{ Probability of identification" } \\
\hline & & Coyote & Dog & Wolf \\
\hline \multicolumn{5}{|c|}{ Barajas (400-1100 AD) } \\
\hline MBo1 & 1.723 & o & 100 & 0 \\
\hline MBO2 & 1.773 & o & 98.9 & 1.0 \\
\hline MBO3 & 1.716 & 。 & 99.9 & $\circ$ \\
\hline \multicolumn{5}{|c|}{ Calixtlahuaca (1380-1450 AD) } \\
\hline MCo1 & 1.637 & 0.1 & 99.8 & o \\
\hline MCO2 & 1.717 & 0.1 & 99.9 & o \\
\hline \multicolumn{5}{|c|}{$J R 74(250-400)$} \\
\hline MChor & 1.708 & o & 100 & $\circ$ \\
\hline \multicolumn{5}{|c|}{ Tizaуиса (350-1500 AD) } \\
\hline МТоз & 1.672 & o & 100 & $\circ$ \\
\hline MTO6 & 1.672 & $\circ$ & 100 & $\circ$ \\
\hline MTO7 & 1.647 & $\circ$ & 99.7 & 0.3 \\
\hline MTo9 & 1.799 & $\circ$ & 100 & o \\
\hline MT12 & 1.663 & $\circ$ & 99.7 & 0.2 \\
\hline MT13 & 1.696 & 0.1 & 99.9 & $\circ$ \\
\hline MT14 & 1.653 & 86.2 & 12.1 & 1.7 \\
\hline MT16 & 1.769 & $\circ$ & 99.9 & 0.1 \\
\hline MT18 & 1.707 & 0.2 & 75.1 & 24.7 \\
\hline MT19 & 1.704 & 2.5 & 96.7 & 0.8 \\
\hline MT21 & 1.692 & 0.1 & 99.6 & 0.4 \\
\hline MT22 & 1.692 & 2.1 & 97.8 & 0.1 \\
\hline MT23 & 1.678 & 0.8 & 98.6 & 0.6 \\
\hline MT24 & 1.627 & 22.7 & 69.7 & 7.6 \\
\hline MT 25 & 1.682 & 0.1 & 80.1 & 19.8 \\
\hline MT26 & 1.696 & o & 100 & o \\
\hline
\end{tabular}

Tab. 2. Probability of identification of the unknown samples based on predictive linear analysis.

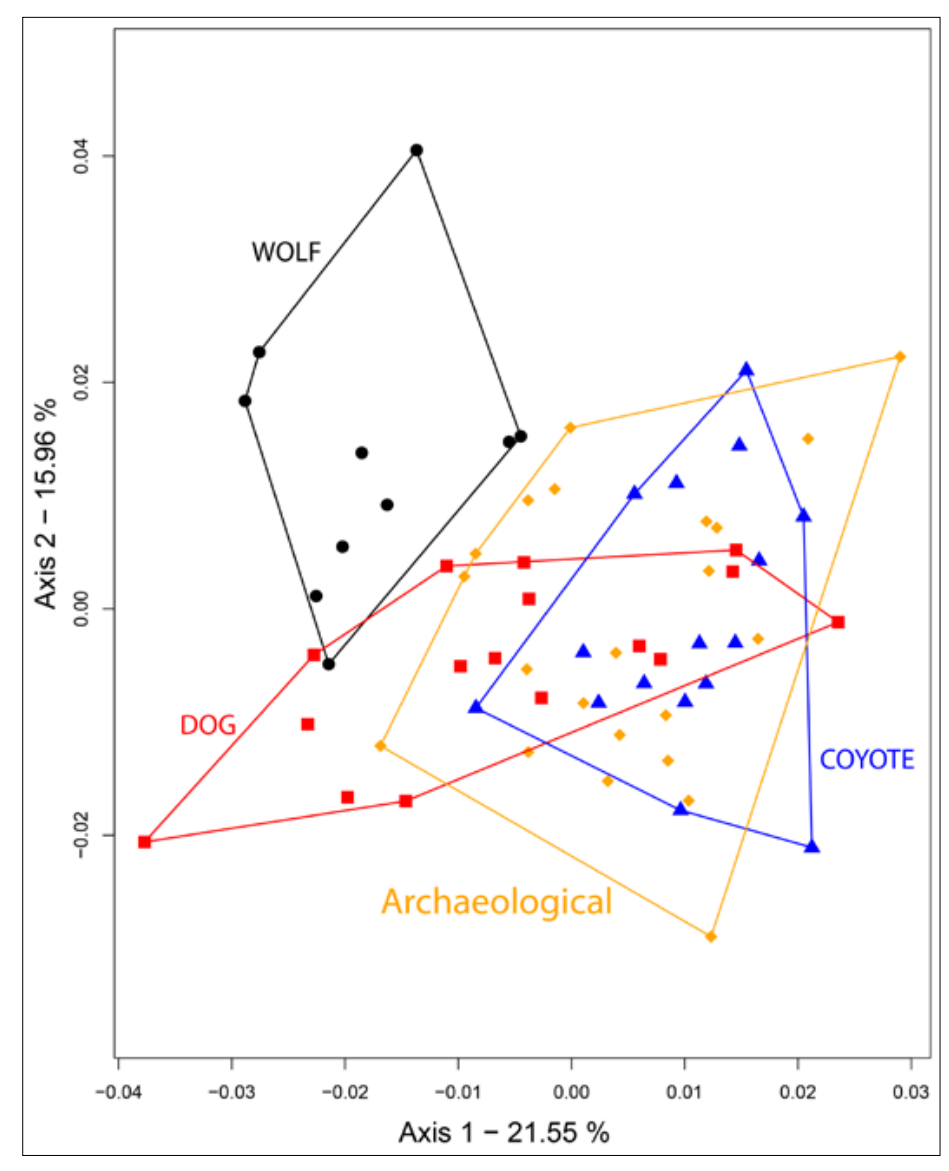

Fig. 4. Shape variation: two first axes of a Principal component analysis.

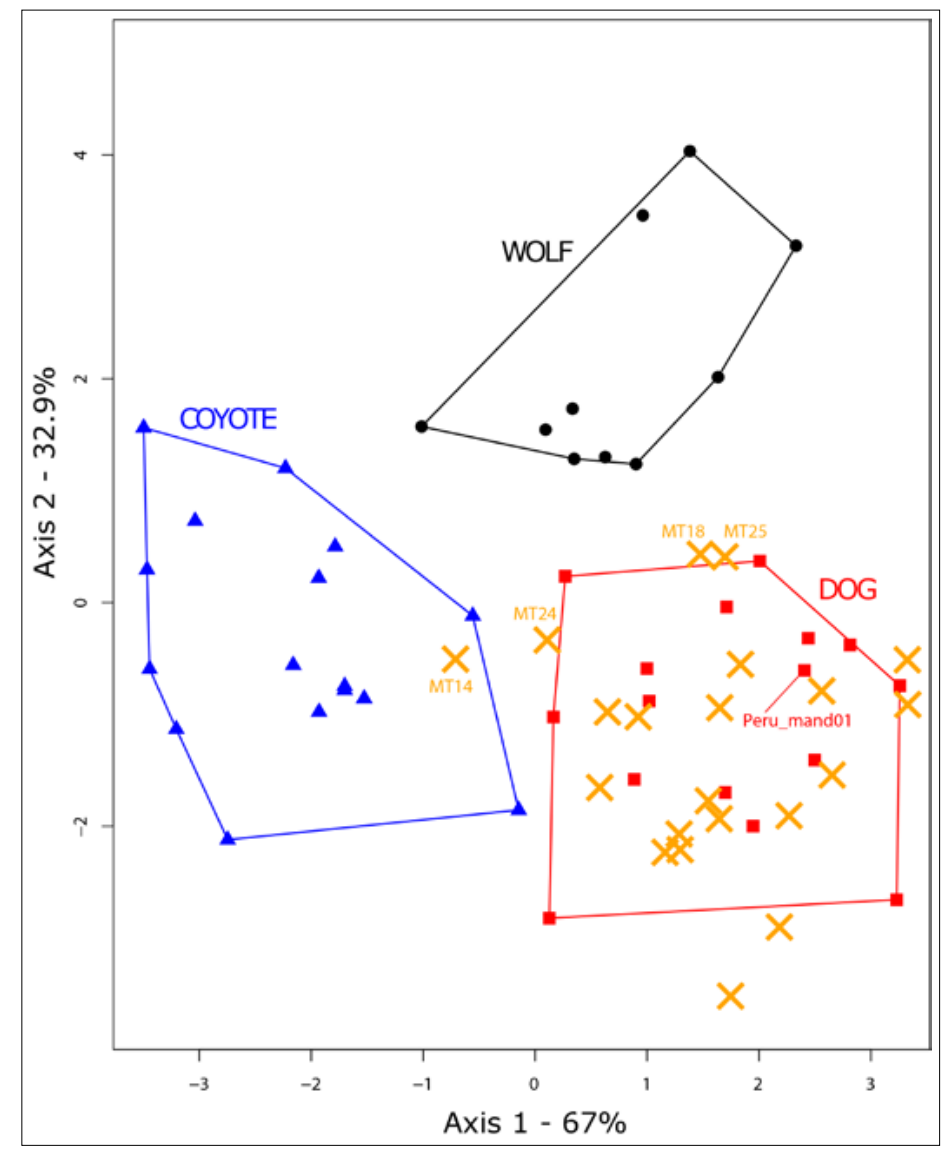

Fig. 5. Linear discriminant analysis on shape. The position of the archaeological specimens was calculated using a predictive linear discriminant analysis

\section{Discussion}

This preliminary study confirms that the CMM analysis of the first lower molar is a promising tool for the taxonomic identification of North American canids. From a set of reference individuals, we show that coyotes, dogs and wolves can be successfully discriminated through their size and shape using a 2D landmark-based approach. Applying this same approach to archaeological samples allows us to discuss more in depth the species distribution and its cultural and ecological implications.

\section{Dogs}

Most of the archaeological first lower molars analysed in this study securely come from dogs (18 (+2 possible dogs) out of 22). This result is consistent with previous zooarchaeological studies showing the constant presence of dogs in central Mexico ${ }^{91}$ In fact, all the individuals from Nogales, JR74 and Calixtlahuaca present a molar morphometry consistent with dogs. The identification in Tizayuca is, however, more problematic. Twelve individuals are confidently identified as dogs whereas two individuals could only be identified as possible dogs due to their lower probability of identification. This variation in the probability of identification may be related to a more diverse tooth shape spectrum in the dogs from Tizayuca. Yet, the dogs from this site show diverse morphotypes, including the presence of possible hairless $\operatorname{dogs}^{92}$. The hypothesis that some individuals might be the result of hybridisations between dogs and wolves or dogs and coyotes is also considered bellow (4.d)

\section{Coyotes}

Although coyotes are quite rare in the archaeological record of central Mexico, one individual from Tizayuca have been identified as a possible

91 Manin \& Lefèvre 2016; Valadez Azúa \& Rodríguez Calicia

92 Manin et al. 2018 coyote on the basis of its tooth shape, with a probability of $86 \%$. The presence of a coyote in this specific site could be related to the high number of faunal remains retrieved during the archaeological exploration (more than 3000 , including 877 canid remains), as a larger amount of bones would increase the probability of identifying scarce or new species $^{93}$. The large number of canid individuals identified in Tizayuca and their prevalence on the site also suggest a major interest for that taxonomic group, whether it was for economic or symbolic purposes. However, while dogs have been found in burials, associated with civic-ceremonial or domestic spaces, the possible coyote mandible was found as isolated and fragmented, in a pit, with very limited contextualisation.

\section{Wolves}

No wolves were confidently identified in our study, although they have been reported in other sites in the region, in particular Teotihuacan and Mexico-Tenochtitlan ${ }^{94}$. In these two sites, their bodies were found in exceptional offerings where they took part in state-level rituals ${ }^{95}$. As none of our samples come from such symbolic context, the absence of wolves is consistent with their peculiar cultural association.

\section{Hybridization between dogs} and wild canids?

Evidence of genetic admixture between dogs and wolves or coyotes has been found in the archaeological record ${ }^{96}$ and amongst modern populations ${ }^{97}$. Discovering the bones of hybrids of dogs and wolves, or coyotes, in the archaeological record

\section{Lyman 2008, 180.}

94 López Luján \& Chávez Balderas 2010; Lopez Lujan et al. 2012; Sugiyama et al. 2014; Valadez Azúa \& Rodriguez Calicia 2009

95 ibid.

96 Ní Leathlobhair et al. 2018

97 Adams et al. 2003; Schmutz et al. 2007 vonHoldt et al. 2011; 2016b. 
is thus plausible. As a matter of fact, some authors have suggested the identification wolf-dog hybrids based on morphoscopic and metric analyses, assuming that first generation hybrids would inherit a mixture of characters from each parent ${ }^{98}$. Nonetheless, the relationship between genotype and phenotype is not strictly cumulative, in particular due to epistatic phenomena where a combination of genes and alleles will interact to produce a specific phenotype. Experimentations have shown that if some hybrids tend to present an intermediate morphology ${ }^{99}$, others display an original phenotype ${ }^{100}$. Questionable specimens MT18 and MT25, and above all MT24, might be the evidence of a significant admixture between dogs and wild canids. However, addressing this question would require to expand the reference collection in three directions. First of all, the use of a larger reference collection for each species is required to ensure the diversity of tooth shape is adequately captured in the analysis. Secondly, the inclusion of known hybrid populations such as the Eastern and the red wolves, in large enough numbers, would provide an overview of the diversity in such groups. Finally, the degree of admixture in these hybrid individuals should be quantified using genetic tools, in order to identify the range of morphological variations in connection with relative dog, wolf and coyote ancestry.

Ecological and cultural impact of the distribution of canids in the archaeological sites of central Mexico

Through this study, we highlight the broad distribution and the prevalence of the dog amongst the canids present in the zooarchaeological record of central Mexico. By its absence in the corpus analysed here, the highly symbolic role of the wolf is comforted. Although it is hard to infer past distribution of a species from its modern distribution, the

100 e.g. Renaud et al. 2009 wolf's ecology and behaviour implies that it would not have been found regularly near human settlements but rather in forested habitats. There are numerous testimonies of the importance of hunting in the Mesoamerican ritual life ${ }^{101}$. While the deer was a prey of choice in different societies, associated with elite rituals and ceremonial hunting ${ }^{102}$, the capture or hunting of wolves could have taken place in the same context.

On the contrary, as a species of open and disturbed environment, the coyote may have thrived in past agricultural landscapes and it can be considered as a commensal species. Its formal identification in the archaeological record has proven to be problematic and often requires the use of ancient $\mathrm{DNA}^{103}$. Using a systematic CMM approach, we suggest that only a small minority of coyotes were present in the archaeological sites of central Mexico, which confirms previous zooarchaeological results. The scarcity of the coyote in the Mesoamerican archaeological record could be related to a cultural bias and a conscious choice of wolves against coyotes in ceremonial paraphernalia and state-level rituals, due to ecological and ethological distinctions. But whereas today coyotes proliferate in central Mexico they may have been only occasional in the past. The development of agropastoralism leading to land clearance and increasing hunting pressure on its natural predator, the wolf, has allowed the coyote to extend its natural distribution during the past 500 years ${ }^{104}$. Its previous natural distribution is not well understood and the mountain range of central Mexico could have represented its southernmost limit. This hypothesis would strengthen previous suggestions that the wild canids represented in the iconography, in particular in the site of Teotihuacan, are wolves rather than coyotes ${ }^{105}$

101 e.g. Olivier 2015.

102 Dehouve 2010; Faugère 2008; Olivier 2015

103 Byrd et al. 2013; Kemp et al. 2017; Monagale et al. 2018.

104 Hidalgo-Mihart et al. 2004; Hody \& Kays 2018.

105 Sugiyama 2014

\section{CONCLUSION AND FUTURE DIRECTIONS}

In this paper, we used a CMM approach to identify first molars of large canids from 4 archaeological sites in central Mexico. We demonstrate that the dog, the wolf and the coyote can be differentiated using the size and shape of their teeth. Using the same approach on unidentified archaeological samples, we succeeded in the confident identification of 18 dogs, as well as two possible dogs and one possible coyote. One sample from the archaeological site of Tizayuca remains unidentified.

Overall, we confirm the prominent place of dogs in ancient Mesoamerica and the typical association of wolf remains and state-level rituals. The scarcity of coyote remains suggest this species was not as highly valued as the two others, whether it was in economic or symbolic terms. The ambiguous identification of some individuals that present an intermediate phenotype also led us to raise the question of the presence of hybrids, although a larger study would be required to fully address this question.

This preliminary study demonstrates the potential of a CMM approach for the identification of canid species in ancient Mesoamerica. However it still relies on a very limited amount of reference individuals that will have to be expanded in the future. The confrontation of the CMM results to a genetic identification, through the analysis of ancient mitochondrial and nuclear DNA, would also be necessary to confirm the species identification and identify the degree of admixture between taxa.

\section{ACKNOWLEDGMENTS}

We wish to thank Norma Valentín, Joaquín Arroyo Cabrales and Fabiola Cuzmán for granting us access to the collection of the Laboratorio de Arqueozoología M. en C. Ticul Álvarez del Instituto Nacional de Antropología e Historia (Mexico city); Cécile Callou and Christine Lefèvre for facilitating the access to the Collections d'anatomie comparee of the Muséum national d'Histoire naturelle (Paris); Myriam Boudadi-Maligne and Jean-Baptiste Mallye for organising the conference Relations Hommes-canidés in Bordeaux in October 2018 and accepting our presentation; an anonymous reviewer for insightful comments. 


\section{BIBLIOGRAPHY}

Adams, D. C., Collyer, M. L. and Kaliontzopoulou, A. (2019): Ceomorph: Software for Ceometric Morphometric Analyses. URL: https://github.com/geomorphR/geomorph

Adams, D. C., Rohlf, F. J. and Slice, D. E. (2004): "Ceometric morphometrics: ten years of progress following the 'Revolution"', Italian Journal of Zoology, $71,5-16$.

Adams, D. C., Rohlf, F. J. and Slice, D. E. (2013): "A field comes of age: geometric morphometrics in the 21st Century", Hystrix, 24, 7-14

Adams, J. R., Leonard, J. and Waits, L. P. (2003): "Widespread occurrence of a domestic dog mitochondrial DNA haplotype in Southeastern US coyotes", Molecular Ecology, 12, 541-546.

Álvarez, T. and Ocaña, A. (1999): Sinopsis de los restos arqueozoológicos de vertebrados terrestres, México.

Amano, N. (2011): The faunal remains of Nagsabaran in Cagayan, Northern Philippines: subsistence strategies in the Late Holocene. MSc thesis, University of the Philippines.

Aranda, M, and Lopez-de-Buen, L. (1995): "Hábitos alimentarios del Coyote (Canis latrans) en la Sierra del Ajusco. México", Acta Zoológica Mexicana (Nueva Serie), 65, 89-99.

Arroyo Cabrales, ]. and Carranza Castañeda, O. (2009): "Los canidos prehistóricos mexicanos antes de la llegada del perro", Archaeobios, 3, 34-45.

van Asch, B., Zhang, A., Oskarsson, M. C. R., Klütsch, C. F. C. Amorim, A. and Savolainen, P. (2013): "Pre-columbian origins of native American dog breeds, with only limited replacement by European dogs, confirmed by mtDNA analysis", Proceedings of the Royal Society B, 280, 1-9.

Balme, J., O'Connor, S. and Fallon, S. (2018): "New dates on dingo bones from Madura Cave provide oldest firm evidence for arrival of the species in Australia", Scientific Reports, 8, 9933 .

Baxter, I. L. and Hamilton-Dyer, S. (2003): "Foxy in furs? A note on evidence for the probable commercial exploitation of the red fox (Vulpes vulpes L.) and other fur bearing mammals in Saxo-Norman (10th -12th century AD) Hertford, Hertfordshire, U.K.", Archaeofauna, 12, 87-94.
Baylac, M. and Friess, M. (2005): "Fourier descriptors, procrustes superimposition and data dimensionality: an example of cranial shape analysis in modern human population", in: Slice, dir., Modern Morphometrics in Physical Anthropology, Developments in Primatology: Progress and Prospects book series (DIPR), 142-165

Blanco, A., Rodríguez, B. and Valadez, R. (2007): "El lobo mexicano (Canis lupus baileyi) en el contexto cultural prehispánico: las fuentes escritas", AMMVEPE, 18, 68-76.

Blanco Padilla, A., Rodríguez Calicia, B. and Valadez Azúa, R. (2009): Estudio de los cánidos arqueológicos del México prehispánico, México.

Bogan, M. A. and Mehlhop, P. (1983): "Systematic relationships of gray wolves (Canis lupus) in Southwestern North Biology, 1, 1-21.

Bond, J. M. (1996): "Burnt offerings: animal bone in AngloSaxon cremations", World Archaeology, 28, 76-88.

Boudadi-Maligne, M. and Escarguel, C. (2014): "A biometric re-evaluation of recent claims for Early Upper Palaeolithic wolf domestication in Eurasia", Journal of Archaeological Science, 45, 80-89.

Boudadi-Maligne, M., Mallye, J.-B., Castel, J.-C., Ferrié, J.G., Crepin, L., Kuntz, D., Vercoutère, C., Soulier, M.-C. and Costamagno, S. (2018): “Loups, chiens et sociétés du Paleólithique Superieur,"in: Costamagno, S., Courichon, L., Dupont, C., Dutour, O., Vialou, D., dir., Animal symbol-

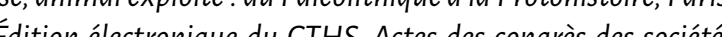
Edion ellectronique du CTHS, Actes des 00

Boudadi-Maligne, M., Mallye, J-B., Langlais, M. and Barshay-Szmidt, C. (2012) : "Des restes de chiens magdaléniens à l'Abri du Morin (Gironde, France). Implications socioéconomiques d'une innovation zootechnique PALEO, 23, 39-54.

Brown, D. E. (2002): The wolf of the Southwest: the making of an endangered species, Silver City

Byrd, B. F., Cornellas, A., Eerkens, J. W., Rosenthal, J. S. Carpenter, T. R., Leventhal, A. and Leonard, J. A. (2013) The role of canids in ritual and domestic contexts new ancient DNA insights from complex hunter-gatherer sites in prehistoric central California", Journal of Archaeological Science, 40, 2176-2189.

Carballo, D. M. (2007): "Implements of state power Weaponery and martially themed obsidian production near the Moon Pyramid, Teotihuacan", Ancient Mesoamerica, 18, 173-190.

Castroviejo-Fisher, S., Skoglund, P., Valadez, R., Vilá, C. and Leonard, J. A. (2011): "Vanishing native American dog lineages", BMC Evolutionary Biology, 11, 1-5

Ceballos, C. \& Arroyo Cabrales, ]. (2012): "Lista actualizada de los mamíferos de México", Revista Mexicana de Mastozoología Nueva Epoca, 2, 27-80.
Clutton-Brock, J. and Hammond, N. (1994): "Hot dogs: comestible canids in Preclassic Maya culture at Cuello Belize", Journal of Archaeological Science, 21, 819-826.

Cucchi, T., Mohaseb, A., Peigné, S., Debue, K., Orlando, L. and Mashkour, M. (2017): "Detecting taxonomic and phylogenetic signals in equid cheek teeth: towards new palaeontological and archaeological proxies", Royal Society Open Science, 4,160997.

Cucchi, T., Hulme-Beaman, A., Yuan, J. and Dobney, K. (2011): "Early Neolithic pig domestication at Jiahu, Henan province, China. Clues from molar shape analyses using geometric morphometric approaches", Journal of Archaeological Science, 38, 11-22.

Cucchi, T., Kovács, Z. E., Berthon, R., Orth, A., Bonhomme, F. Evin, A., Siahsarvie, R. Darvish, ]. Bakhshaliyev, V and Marro, C. (2013): "On the trail of Neolithic mice and men towards Transcaucasia. zooarchaeological clues from towards ivan (Azerbaijan)" Biological Journal of the linnean Society, 108, 917-928.

Day, J. S., Butterwick, K. and Pickering, R. B. (1996) "Archaeological interpretations of West Mexican ceramic art from the Late Preclassic period: three figurine projects", Ancient Mesoamerica, 7, 149-161.

Dehouve, D. (2010): "Un ritual de cacería. El conjuro para cazar venados de Ruiz de Alarcón", Estudios de Cultura Nahuatl, 40, 299-331.

Díaz del Castillo, B. (1996): La conquête du Mexique, Paris.

Drake, A. C., Coquerelle, M., Kosintsev, P. A., Bachura, O. P. Sablin, M., Gusev, A. V., Lacey S. Fleming, L. S. and Losey, R. J. (2017). "Three-dimensional geometric morphometric analysis of fossil canid mandibles and skulls", Scientific Reports, 7, 9508 .

Drake, A. C. \& Klingenberg, C. P. (2010): "Large-scale diversification of skull shape in domestic dog: disparity and modularity", The American Naturalist, 175, 289-301.

Emery, K. F. (1999): "Continuity and variability in Postclassic and Colonial animal use at Lamanai and Tipu, Belize" in: White, C.D., dir., Reconstructing Ancient Maya Diet University of Utah Press, Salt Lake City, 61-83.

Emery, K. F. (2004): "In search of the 'Maya diet'. is regional comparison possible in the Maya tropics?", Archaed $13,37-55$

Equihua Manrique, J. C., Tirado Balandrán, A. L., Ponce Ordaz, K. P., Nicolás Careta, C., Hernández Balderas, T. López Martínez, H., Padilla Gutiérrez, E. F., Riego Ruíz, S., Cervantes Alejandre, C. S., Montes Guerrero, T., López Martínez, J. B., Monterroso Rivas, P. N., Ponce de León R. H. and Ojeda Güitró, E. (2008): Proyecto Salvamento Arqueológico Tizayuca 2006. Informe. Secuencias
Estratigráficas y Conjuntos Arquitectónicos, Tomo I. Final Estratigráficas y Conjuntos Arquitectónicos, Tomo I. Final in e Historia

Evin, A., Cucchi, T., Cardini, A., Vidarsdottir, U. S., Larson, C. and Dobney, K. (2013): "The long and winding road: identifying pig domestication through molar size and shape", Journal of Archaeological Science, 40, 735-743.

Evin, A., Cucchi, T., Escarguel, C., Owen, J., Larson, C. Vidarsdottir, U. S. and Dobney, K. (2014): "Using traditional biometrical data to distinguish west palearctic wild boar and domestic pigs in the archaeological record: new methods and standards", Journal of Archaeological Science, 43, 1-8.

Evin, A., Dobney, K., Schafberg, R., Owen, J., Vidarsdottir, U. S., Larson, C. and Cucchi, T. (2015). Phenotype and animal domestication: a study of dental variation between domestic, wild, captive, hybrid and insular Sus scrofa" BMC Evolutionary Biology, 15, 1-16

Faugère, B. (2008): "Le cerf chez les anciens P'urhépecha du Michoacán (Mexique) : guerre, chasse et sacrifice", Journal de la Société des Américanistes, 94, 109-142.

Fillios, M. A. and Taçon, P. S. C. (2016): "Who let the dogs in? A review of the recent genetic evidence for the introduction of the dingo to Australia and implications for the movement of people", Journal of Archaeological Science: Reports, 7, 782-792

Fisher, A. E. (2019): "When is a wolf a dog? combined geometric morphometrics and stable isotope analyses for differentiating wild from domestic canids on the Northern Plains", Plains Anthropologist, 64, 316-349.

Fritzell, E. K. and Haroldson, K. J. (1982): "Urocyon Cinereoargenteus", Mammalian Species, 189, 1-8.

García Moreno, ]., Matocq, M. D., Roy, M. S., Ceffen, E. and Wayne, R. K. (1996): "Relationships and genetic purity of the endangered Mexican wolf based on analysis of microsatellite loci", Conservation Biology, 10, 376-389.

Centry, A., Clutton-Brock, J. and Croves, C. P. (2004): "The naming of wild animal species and their domestic derivatives", Journal of Archaeological Science, 31, 645-651.

Germonpré, M., Sablin, M. V., Stevens, R. E., Hedges, R. E. M. Hofreiter, M., Stiller, M. and Després, V. R. (2009): "Fossil dogs and wolves from Palaeolithic sites in Belgium, the Ukraine and Russia: osteometry, ancient DNA and stable isotopes", Journal of Archaeological Science, 36, 473-490.

Cerry, J. P. (1997): "Bone isotope ratios and their bearing on elite privilege among the Classic Maya", Ceoarchaeology: An International Journal, 12, 41-69.

Cötz, C. M. (2008): "Coastal and inland patterns of faunal exploitation in the prehispanic northern Maya lowds", Quaternary International, 191, 154-16

Crandal-d'Anglade, A., Albizuri, S., Nieto, A., Majó, T., Agustí, B., Alonso, N., Antolín, F., López, J. B., Moya, A. Rodríguez, A. and Palomo, A. (2019): "Dogs and foxes in Early-Middle Bronze Age funerary structures in the Northeast of the Iberian peninsula: human control of canid diet at the sites of Can Roqueta (Barcelona) and Minferri (Lleida)", Archaeological and Anthropological Sciences, 11, 3949-3978. 
Guedes Milheira, R., Loponte, D. M., García Esponda, C., Acosta, A. and Ulguim, P. (2017): "The first record of a pre-Columbian domestic dog (Canis lupus familiaris) in Brazil", International Journal of Osteoarchaeology, 27, 488- 494 .

Guthmann, E., Lefranc, P. and Arbogast, R.-M. (2016): "Un dépôt de renard roux (Vulpes vulpes) du 4e millénaire av. 1-C. à Entzheim "Les Terres de La Chapelle" (Bas-Rhin) offrande ou sépulture animale ?", RAE, 65, 257-268.

Hall, E. R. and Kelson, K. R. (1959): The Mammals of North America, vol. 2, New York.

Hammer, Ø., Harper, D. A. T. and Ryan, P. D. (2001): "PAST: Paleontolgical statistics software package for education and data analysis", Palaeontologica Electronica, 4, 1-9,

Harding, L. E., Heffelfinger, J., Paetkau, D., Rubin, E., Dolphin, J. and Aoude, A. (2016): "Cenetic management and setting recovery goals for Mexican wolves (Canis lupus baileyi) in the wild", Biological Conservation, 203, 151-159.

dalgo-Mihart, M. C., Cantu-Salazar, L., Gonzalez-Romero, A. and Lopez-Conzalez, C. A. (2004): "Historical and present distribution of coyote (Canis latrans) in Mexico and Central America", Journal of Biogeography, 31, 2025-2038.

Hidalgo-Mihart, M. C., Cantu-Salazar, L., Lopez-Conzalez, C. A., Martinez-Meyer, E. and Conzález-Romero, A. (2001) "Coyote (Canis latrans) food habits in a tropical decidNaturalist, 146, 210-216.

Hillson, S. (2005): Teeth, Cambridge.

Hody, J. W. and Kays, R. (2018): "Mapping the expansion of coyotes (Canis latrans) across North and Central America", Zookeys, $759,81-97$

Hulme-Beaman, A., Claude, ]., Chaval, Y., Evin, A., Morand S., Vigne, J.-D., Dobney, K. and Cucchi, T. (2018): "Dental shape variation and phylogenetic signal in the Rattini tribe species of Mainland Southeast Asia", Journal of Mammalian Evolution, 26, 435-446.

Huster, A. C. and Smith, M. E. (2015): "A new archaeological chronology for Aztec-period Calixtlahuaca, Mexico", Latin American Antiquity, 26, 3-25.

Iljin, N. A. (1941): "Wolf-dog Cenetics", Journal of Cenetics, 42:359-414.

Janssens, L.A.A. and Lawler, D.F. (2019) "Were foxes really domesticated, and were dogs really beasts of burden, during the Bronze Age in Northeast Spain?", Archaeological and Anthropological Sciences, 11, 3995-3998.

Jarquin P., A. M. and Martinez Vargas, E. (2004): "Ritos y Mitos Prehispanicos Nahuas En Dos Tumbas de La Campana, Colima", Estudios de Cultura Náhuatl, 35, 75-87. Jernvall, J. and Thesleff, I. (2000): "Reiterative signalling and
patterning during mammalian tooth morphogenesis", Mechanisms of Development, 92, 19-29.
Kemp, B. M., Judd, K., Monroe, C., Eerkens, J. W., Hilldorfer L., Cordray, C., Schad, R., Reams, E., Ortman, S. C. and Kohler, T. A. (2017): "Prehistoric mitochondrial DNA of domesticate animals supports a 13th century exodus from the Northern US Southwest", PLOS ONE, 12 , e0178882

Kubler, C. (1972): "Jaguars in the valley of Mexico", in: Benson, 19-44.

Kupczik, K., Cagan, A., Brauer, S. and Fischer, M. S. (2017) The dental phenotype of hairless dogs with FOXI3 haploinsufficiency", Scientific Reports, 7, 5459

Larson, G. and Bradley, D. C. (2014) "How much is that in dog years? The advent of canine population genomics", PLoS Cenetics, 10, e1004093.

Larson, C., Karlsson, E. K., Perri, A., Webster, M. T., Ho, S.Y W., Peters, ]., Stahl, P. W., Piper, P. J., Lingaas, F., Fredholm M., Comstock, K. E., Modiano, J. F., Schelling, C., Agoulnik, A. I., Leegwater, P. A., Dobney, K., Vigne, J.-D., Vilà, C. Andersson, L. and Lindblad-Toh, K. 2012. "Rethinking dog domestication by integrating genetics, archeology, and biogeography", Proceedings of the National Academy of Sciences of the United States of America, 109, 8878-8883.

Lawrence, B. (1967): "Early domestic dogs", Zeitshrift Für Säugetierkunde, 32, 44-59.

Lawrence, B. and Bossert, W. H. (1967): "Multiple character analysis of Canis lupus, latrans and familiaris, with a discussion of the relationships of Canis niger", American

Leonard, J. A., Wayne, R. A., Wheeler, ]., Valadez Azúa, R., Guillen, S. and Vilá, C. (2002): "Ancient DNA evidence for Old World origin of New World dogs", Science, 298, 1613-1616.

Leopold, A. S. (1959): Wildlife of Mexico, the game birds and mammals, Berkley.

López Austin, A. and López Luján, L. (2012) : Le Passé Indigène. Histoire Pré-coloniale Du Mexique, Paris.

López Luján, L., Chávez Balderas, X., Zuñiga-Arellano, B. Aguirre Molina, A. and Valentín, N. (2012): "Un portal al inframundo. Ofrendas de animales sepultadas al pie del Templo Mayor de Tenochtitlan" Estudios de Cultura Nahuatl, 44, 9-40.

López Luján, L. and Chávez Balderas, X. (2010): "Al pie del Templo Mayor: excavaciones en busca de los soberanos mexicas", in: López Luján, L. \& McEwan, C., dir Moctezuma II. Tiempo y destino de un governante, Instituto nacional de antropología e historia, 294-303

Losey, R. J., Bazaliiskii, V. I., Garvie-Lok, S., Cermonpré, M. Leonard, J. A., Allen, A. L., Katzenberg, M. A. and Sablin M. V. (2011): "Canids as persons: Early Neolithic dog and wolf burials, Cis-Baikal, Siberia", Journal of Anthropological Archaeology, 30,174-189.

Lucas, S. C., Alvarado, C. E. and Vega, E. (1997): "The Pleistocene mammals of Costa Rica", The Society of Vertebrate Palaeontology, 17,413-427.
Lyman, R. L. (2008): Quantitative Paleozoology, Cambrige.

Manin, A. (2015): "Utilisation matérielle et symbolique des animaux dans le nord de la Mésoamérique entre le Classique et la Conquête (200-1521 apr. ].-C.)" PhD thesis, Muséum national d'Histoire naturelle.

Manin, A. (2017a): "Archéozoologie, géochimie et concepts de domestication en Mésoamérique - Zooarchaeology, geochemistry, and concepts of domestication in Mesoamerica", Annales de La Fondation Fyssen, 32, 141-154.

Manin, A. (2017b): "Estudio de los restos de fauna procedentes del sitio de Calixtlahuaca, Estado de México, México" Technical report Proyecto Arqueológico Calixtlahuaca.

Manin, A. (in prep): "Caza y cría de animales en el valle de Acámbaro a partir desl estudio de la fauna vertebrada de El Mezquital - Los Azules", in: Faugère

Manin, A. \& Lefèrre, C. (2016): "The use of animals in Northern Mesoamerica, between the Classic and the Conquest (200-1521 AD). An attempt at regional synthesis on central Mexico", Anthropozoologica, 51, 127-147.

Manin, A. and Lefèvre, C. (2018) " "Utilización material y simbólica de los animales en Vista Hermosa", in: StresserPéan, C., Vista Hermosa. Nobles, artesanos y mercaderes en los confines del mundo huesteco. Vol men III: El arte y la vida en la Huesteca posclásica, 3, 9-50

Manin, A., Ollivier, M., Bastian, F., Zazzo, A., Tombret, O., Equihua Manrique, J. C. and Lefèvre, C. (2018): "Can we identify the Mexican hairless dog in the archaeological record? Morphological and genetic insights from Tizayuca, Basin of Mexico", Journal of Archaeological Science, 98, 128-136.

Martinez de Leon Marmol, B. L. and Reyes Carlo, I. (2007) "Los perros como indicador estacional en los enterramientos humanos prehispánicos. Un caso de estudio en el valle de Zapotitlan, Puebla", Estudios de Antropología Biológica, 13, 347-360.

Matos Moctezuma, E. (1994): "Mesoamérica”, in: Manzanilla and López Luján, vol.1, 95-119.

Merkle, J. A., Krausman, P. R., Stark, D. W., Oakleaf, J. K. and Ballard, W. B. (2009): "Summer diet of the Mexican gray wolf (Canis lupus baileyi)", The Southwestern Naturalist, 54, 480-524.

Monagle, V., Conrad, C. and Jones, E. L. (2018): "What makes a dog? Stable isotope analysis and human-canid relationships at Arroyo Hondo Pueblo" Open Quaternary, 4, 6 .

Morey, D. F. (2006): "Burying key evidence: the social bond between dogs and people", Journal of Archaeological Science, 33, 158-175.

Morey, D. F. (2014): "In search of Paleolithic dogs: a quest with mixed results", Journal of Archaeological Science, 52 , 300-307

Morey, D. F. and Jeger, R. (2017): "From wolf to dog: Late Pleistocene ecological dynamics, altered trophic strategies, and shifting human perceptions", Historical Biology, 29, 895-903

de Moura Bubadué, J., Cáceres, N., dos Santos Carvalho, R. and Meloro, C. (2016): "Ecogeographical variation in skull shape of South-American canids: abiotic or biotic processes?", Evolutionary Biology, 43, 145-159.

Napierala, H. and Uerpmann, H.P. (2012): "A 'new Palaeolithic dog from Central Europe", International Journal of Osteoarchaeology, 22, 127-137.

Ní Leathlobhair, M., Perri, A. R., Irving-Pease, E. K., Witt, K. E., Linderholm, A., Haile, J., Lebrasseur, O., Ameen, Crockford S. 1 Devault A Dimopoulos, E. A, Eldridge M., Enk, J., Copalakrishnan, S., Gori, K., Grimes, V. Cuiry, E. Hansen, A. ]. Hulme-Beaman A. Johnson, ] Kitchen, A., Kasparov, A. K., Kwon, Y.-M., Nikolskiy, P. A. Peraza Lope, C. Manin A. Martin, T Meyer M. Myers K. N., Omura, M., Rouillard, ].-M., Pavlova, E. Y., Sciulli, P., Sinding. M.-H. S., Strakova, A., Ivanova, V. V. Widga, C., Willerslev, E., Pitulko, V. V., Barnes, B., Gilbert, M. T. P., Dobney, K. M., Malhi, R. S., Murchison, E. P. Larson G. and Frantz, L. A. F. (2018): "The evolutionary history of dogs in the Americas", Science, 361, 81-85.

Olivier, C. (2015): Caceria, sacrificio y poder en Mesoamérica. Tras las huellas de Mixcoatl, "Serpiente de Nube", México. Olsen, S. J. (1985): Origins of the domestic dog, Tuscon.

Ovodov, N. D., Crockford, S. J., Kuzmin, Y. V., Higham, T. F. C., Hodgins, C. W. L. and van der Plicht, J. (2011): "A 33,000 -year-old incipient dog from the Altai moundisupted by the Last Clacial Maximum" PLOS ONE, 6,

Pereira, G. (2008) : "'Larchéologie de la Mésoamérique Septentrionale vue depuis le massif de Barajas (Guanajuato)", Les Nouvelles de larchéologie, 111/112, 101-106.

Perri, A. (2016) : "A Wolf in dog's clothing: initial dog domestication and Pleistocene wolf variation", Journal of Archaeological Science, 68, 1-4.

Pionnier-Capitan, M. (2010): La domestication du chien en Eurasie: étude de la diversité passée, approches ostéoarcheoologiques, morphométriques et paleogénétiques. PhD thesis, École Normale Supérieure de Lyon

Pionnier-Capitan, M., Bemilli, C., Bodu, P., Célérier, G., Ferrié, J.-C., Fosse, P., Garcià, M. and Vigne, J.-D. (2011): "New evidence for Upper Palaeolithic small domestic dogs in South-Western Europe", Journal of Archaeological Science, 38, 2123-2140.

Pluskowski, A. (2006): "Where are the wolves? Investigating the scarcity of European grey wolf (Canis lupus lupus) remains in Medieval archaeological contexts and its implications, International Journal of Osteoarchaeology, 16 
Porter, M. (1956): "Excavations at Chupicuaro, Guanajuato, Mexico", Transactions of the American Philosiphical Society, 46, 515-637.

Prates, L., Prevosti, F. J. and Berón, M. (2010): “First records of Prehispanic dogs in southern South America (PampaPatagonia, Argentina)", Current Anthropology, 51, 273-280.

$R$ Core Team (2019): R: A language and environment forstatistical computing. URL: https://www.R-project.org/.

Reed, J. E., Ballard, W. B., Cipson, P. S., Kelly, B. T., Krausman, P. R., Wallace, M. C. and Wester, D. B. (2006): "Diets of free ranging Mexican gray wolves in Arizona and New Mexico", Wildlife Society Bulletin, 34, 1127-1133.

Renaud, S., Alibert, P. and Auffray, J.-C. (2009): "Mandible shape in hybrid mice", Naturwissenschaften, 96, 1043-1050.

Rodríguez Calicia, B., Valadez Azúa, R., Pereira, C., Viniegra Rodríguez, F., Olmos Rodríguez, K. and Blanco Padilla, A. (2001): "Restos arqueozoológicos de perros (Canis familiaris) encontrados en el sitio de Cuadalupe estado de Michoacán", AMMVEPE, 12, 199-209.

Rohlf, F J. (2015): "TpsDig, digitize landmarks and outlines, Version 2.19". URL: https://life.bio.sunysb.edu/morph/

Russell, N. (2002): "The wild side of animal domestication", Society \& Animals, 10, 285-302.

de Sahagun, B. (1829): Historia general de las cosas de Nuevo España vol.1, México.

de Sahagun, B. (1830): Historia general de las cosas de Nueva España vol.2, México.

Schlager, S. (2017): “Morpho and Rvcg- Shape Analysis in R", in: Zheng, Li and Szekely, 217-256.

Schmitt, E. and Wallace, S. (2014): "Shape change and variation in the cranial mophology of wild canids (Canis lupus, Canis latrans, Canis rufus) compared to domestic dogs (Canis familiaris) using geometric morphometrics", International Journal of Osteoarchaeology, 24, 42-50.

Schmutz, S. M., Berryere, T. C., Barta, J. L., Reddick. K. D. and Schmutz, J. K. (2007): "Agouti sequence polmorphisms in coyote, wolves and dogs suggest hybridization" Journal of Heredity, 98, 351-355.

Seetah, K., Cucchi, T., Dobney, K. and Barker, C. (2014): "A geometric morphometric re-evaluation of the use of dental form to explore differences in horse (Equus caballus) populations and its potential zooarchaeological application", Journal of Archaeological Science, 41, 904-910.

Seler, E. (1996): "The animal pictures of the Mexican and Mayan manuscripts", in: Collected works in Mesoamerican linguistics and archaeology vol.5, 165-340.

Shirokova, V., Jussila, M., Hytönen, M. K., Perälä, N., Drögemüller, C., Leeb, T., Lohi, H., Sainio, K., Thesleff, 1. and Milkola, M. L. (2013) "Expression of Foxis is regDevelopmental Dynamics, 242, 593-603.
Sugiyama, N. (2014): Animals and sacred mountains: how ritualized performances materialized state-ideologies at Teotihuacan, Mexico. PhD thesis, Harvard University,

Sugiyama, N., Pérez, C., Rodríguez, B., Torres, F. and

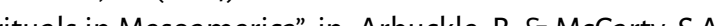
dir Animalsand inequality in the Ancient World University

Sugiyama, S. and López Luján, L. (2006): "Simbolismo y función de los entierros dedicatorios de la Pirámide de la Luna en Teotihuacan", in: Lopez Luján, L., Carrasco, D., Cué, L., dir., Arqueología e historia del Centro de México. Homenaje a Eduardo Matos Moctezuma, Instituto naciona de antropología e historia, 131-151.

Thesleff, I. (2006): “The genetic basis of tooth development and dental defects", American Journal of Medical Cenetics Part A, 14, 2530-2535.

Tomaszewski, B. M. and Smith, M. E. (2011): "Polities, territory and historical change in Postclassic Matlatzinco (Toluca Valley, Central Mexico)", Journal of Historical Ceography, 37, 22-39.

Valadez Azúa, R., Blanco Padilla, A., Rodríguez Calicia, B. and Pérez Roldán, C. (2013): "The dog in the Mexican archaeozoological record", in: Cötz, C. M. \& Emery, K. F. dir., The Archaeology of Mesoamerican Animals, Lockwood press, 557-582.

Valadez Azúa, R. and Rodríguez Calicia, B. (2014): "Uso de la fauna, estudios arqueozoológicos y tendencias alimenAn en culturas prehispánicas del centro de México", Antropología, 48, 139-166.

Valadez Azúa, R. and Rodríguez Calicia, B. (2009): Canidos presentes en el proyecto Tuneles y cuevas de Teotihuacan", in: Manzanilla Naim, L. R., dir., Obras 1, El inframundo de Teotihuacan. Ocupaciones post-teotihuacanas en los tunels al este de la pirámide del sol, vol. III, El ambiente el hombre, El colegio nacional, 573-669.

Valadez Azúa, R., Rodríguez Galicia, B., Manzanilla, L. and Tejeda, S. (2006): "Dog-wolf hybrid biotype reconstruction from the archaeological city of Teotihuacan in Prehispanic central Mexico", in: Snyder, L. M. \& Moore, Symbolic Interaction gth ICAZ Conference, Durham, 2002,

Valentín Maldonado, N. (1997): "Análisis del material zoológico procedente de los sitios arqueológicos de Jonuta, Tabasco y Campeche, México", in: Arroyo Cabrales, ]. \& Polaco, ]., dir., Homenaje al profesor Ticu Álvarez, Colección Científica, 357, México, 343-366.

Valenzuela-Lamas, S., Baylac, M., Cucchi, T. and Vigne, '].-D. (2011): "House mouse dispersal in Iron Age spain: a geometric morphometrics appraisal", Biological Journal of the Linnean Society, 102, 483-497.

Vigne, J.-D. (2011): "The origins of animal domestication and husbandry: a major change in the history of humanity and the biosphere", Comptes Rendus Biologies 334, 171-181.
vonHoldt, B. M., Cahill, J. A., Fan, Z., Gronau, I., Robinson, J., Pollinger, J. P., Shapiro, B., Wall, J. and Wayne, R. K. (2016a): "Whole-genome sequence analysis shows that two endemic species of North American wolf are admixtures of the coyote and gray wolf", Science Advances, 2, e1501714.

vonHoldt, B. M., Kays, R., Pollinger, J. P. and Wayne, R. K. (2016b): "Admixture mapping identifies introgressed genomic regions in North American canids", Molecular Ecology, 25, 2443-2453.

vonHoldt, B. M., Pollinger, J. P., Earl, D. A., Knowles, ]. C., Boyko, A. R., Parker, H., Geffen, E., Pillot, M., Jedrzejewski, W., Jedrzejewska, B., Sidorovich, V., Greco, C., Randi, E., Musiani, M., Kays, R., Bustamante, C. D., Ostrander, E. A. Novembre, J. and Wayne, R. K. (2011): "A genome-wide perspective on the evolutionary history of enigmatic wolf-like canids", Cenome Research, 21, 1294-1305.

Wayne, R. K., Lehman, N. Allard, M. W. and Honeycutt R. L. (1992): "Mitochondrial DNA variability of the gray wolf: genetic consequences of population decline and habitat fragmentation", Conservation Biology, 6, 559-569.

Walker, D. N. \& Frison, C. C. (1982): "Studies on Amerindian dogs, 3: Prehistoric wolf/dog hybrids from the Northwestern plains", Journal of Archaeological Science, 9
White, C. D. 2004. "Stable isotopes and the human-animal interface in Maya biosocial and environmental systems", Archaeofauna, 13, 183-198

White, C. D., Pohl, M. E. D. D. Schwarcz, H. P. and Longstaffe F. ]. (2001): "Isotopic evidence for Maya patterns of deer and dog use at Preclassic Colha", Journal of Archaeological

White, C. D. and Schwarcz, H. P. (1989): "Ancient Maya diet as inferred from isotopic and elemental analysis of human bone", Journal of Archaeological Science, 16, 451-474.

White, C. D., Pohl, M. E. D. D., Schwarcz, H. P. and Longstaffe, F. J. (2004): "Feast, field and forest: Deer and dog diMayan zoorchaeolay: new directions in method and theory. Monograph vol. 51, 141-158.

Wilson, D. E. and Reeder, D. A. E. (2005): Mammals Species of the World, 3rd edition, Baltimore.

Zeder, M. A., Emshwiller, E., Smith, B. D. and Bradley, D C. (2006). "Documenting domestication: the intersection of ge

Durelie Manin, Marie Sklodowska-Curie Fellow, University of York Department of Archaeology; Associate researcher

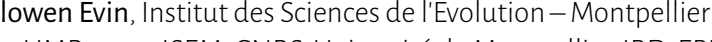
UMR 5554-ISEM, CNRS, Universite de Montpellier, IRD, EPHE

\section{etrouvez la version en ligne gratuite}

(c) (i) (2) 
